\title{
Hidratación y microestructura de cemento Portland sustituido parcialmente con sílice ultrafina
}

\author{
Hydration and microstructure of Portland cement partially \\ substituted with ultrafine silica
}

\author{
L. Y. Gómez-Zamorano(*), J. I. Escalante(**)
}

Recepción/Received: 24-I-08

Aceptación/Accepted: 22-IX-08

Publicado online/Online publishing: 20-XI-09

\section{RESUMEN}

Se investigaron pastas de cemento Portland sustituido con un desecho geotérmico, subproducto de la generación de electricidad en plantas que emplean recursos geotérmicos. El desecho está compuesto principalmente de sílice amorfa de tamaño nanométrico, con cloruros de sodio y potasio. Se investigaron cementos con niveles de substitución de 0,10 y $20 \%$, curados a 20 y $60{ }^{\circ} \mathrm{C}$. En presencia del desecho geotérmico, se observó por Difracción de rayos $X$ cuantitativa que la hidratación de las fases del clínker se aceleró; además mediante microscopía electrónica de barrido se encontró una disminución en la porosidad y un intenso consumo de hidróxido de calcio por la reacción puzolánica. Sin embargo, para pastas con $20 \%$ de desecho geotérmico, se observó agrietamiento con la presencia de gel de reacción álcali sílice y ettringita; fue más acentuado a $60^{\circ} \mathrm{C}$ y no se observó para pastas de cemento puro y con $10 \%$ de desecho. La presencia de las fases nocivas se atribuye a la formación de sal de Friedel en las etapas iniciales de hidratación, promovida por los cloruros provenientes del desecho geotérmico.

Palabras clave: desecho geotérmico, grado de hidratación, ettringita, gel de reacción álcali-sílice, cementos compuestos.

\section{SUMMARY}

Geothermal waste, a by-product of steam power plants that use geothermal underground resources, was studied as a possible replacement for Portland cement. This waste consists primarily in amorphous nanometric silica with traces of sodium and potassium chlorides. The replacement ratios studied were 0, 10 and $20 \%$ in cements cured at 20 and $60^{\circ} \mathrm{C}$. X-ray diffraction analysis showed that clinker phase hydration took place earlier in the presence of the geothermal waste. Scanning electron microscopy, in turn, revealed a reduction in porosity and intense calcium hydroxide consumption as a result of the pozzolanic reaction. The pastes containing $20 \%$ waste, however, an intense cracking was observed due to the formation of alkali silica reaction gel and ettringite. Cracking was more prominent at $60^{\circ} \mathrm{C}$ but was not observed in either the neat cement or the blend with 10 $\%$ waste. The presence of these detrimental phases was attributed to the formation of Friedel's salt in the initial hydration stages, induced by the chlorides in the geothermal material.

Keywords: geothermal waste, degree of hydration, ettringite, alkali silica reaction gel, composite cements.

(*) Universidad Autónoma de Nuevo León (Monterrey, México).

(**) Centro de Investigación y de Estudios Avanzados del Instituto Politécnico Nacional (Saltillo, México). 


\section{INTRODUCCIÓN}

La problemática del manejo de residuos industriales requiere una atención especial debido a las consecuencias ecológicas que representa. Diversos residuos industriales pueden ser incorporados como aditivos o sustitutos al Cemento Portland Ordinario (CPO) en los materiales de construcción, dando lugar a los denominados "cementos compuestos" (1). El empleo de materiales de reemplazo de CPO permite una reducción en el costo energético y en la generación de $\mathrm{CO}_{2}$ asociados a su uso y fabricación. Un gran número de investigaciones relacionadas con el uso de varios materiales de reemplazo del CPO han demostrado que tal práctica mejora las propiedades de morteros y hormigones base CPO; el incremento en la durabilidad de estos últimos está relacionado con propiedades macroscópicas como resistencia a la compresión, resistencia al ataque químico y estabilidad dimensional, entre otras, las cuales dependen de la microestructura del cemento hidratado.

Uno de estos materiales con potencial es el residuo de la producción de energía eléctrica mediante la extracción de calor del subsuelo, en las plantas geotérmicas a base de salmuera. La práctica de esta tecnología se ha incrementado considerablemente en años recientes, debido a que es una fuente de energía limpia, generalmente renovable, y de menor costo relativo a otras formas de generación de energía. Sin embargo, una de las mayores desventajas de dicha tecnología es la generación y disposición de grandes cantidades de desechos, que frecuentemente impide la proliferación de las plantas de energía producida a partir de salmuera geotérmica en muchas partes del mundo (2). Dicho desecho, denominado Desecho Geotérmico (DG), es obtenido de la mezcla de salmuera y vapor (presurizados naturalmente), que pasa a través de diferentes etapas de extracción de calor. Conforme la temperatura se reduce (inicialmente $\sim 200{ }^{\circ} \mathrm{C}$ ), de la mezcla se precipita sílice amorfa de tamaño nanométrico, junto con cloruros de sodio y potasio. El precipitado causa serios problemas ya que se deposita en las tuberías como una cascarilla que crece varias pulgadas por mes y debe ser removida periódicamente (3). Además de estas incrustaciones, una fracción de salmuera remanente se reinyecta al subsuelo y el resto se deposita en lagunas de evaporación que contienen miles de toneladas de este DG. La planta geotérmica de Cerro Prieto en Baja California, México, genera aproximadamente 50.000 toneladas anuales de este DG, el cual no tiene hoy una aplicación. En base a esto, el objetivo de este trabajo fue el de estudiar al DG como reemplazo del CPO lo cual puede presentar una solución al gran problema ecológico que representa actualmente. La explotación de tal cantidad de DG podría beneficiar alrededor de 0,5 millones de toneladas de CPO con un nivel de reemplazo del $10 \%$, lo que puede traducirse en una mejora potencial en la calidad de

\section{INTRODUCTION}

Industrial waste management is an issue of particular importance due to the environmental consequences involved. Certain types of industrial waste can be included as additions to or replacements for ordinary Portland cement (OPC) in construction materials, in what are known as "blended (or composite) cements" (1). The use of replacement materials in OPC lowers energy costs and the $\mathrm{CO}_{2}$ emissions associated with its manufacture. Any number of studies on including replacement materials in OPC have shown that this practice improves OPC mortars and concretes. Enhanced concrete durability, in particular, is related to macroscopic properties such as compressive strength, resistance to chemical attack and dimensional stability, which depend on the microstructure of the hydrated cement.

The waste from electric power generation in geothermal plants that extract heat from underground brine is a potential cement replacement. The use of this generation technology has increased substantially in recent years because the source is clean, usually renewable and less costly than other forms of electric energy production. The generation of large volumes of waste, however, is a significant drawback to this technology that has deterred the proliferation of geothermal brine plants in many areas of the world (2). The by-product, known as geothermal waste $(G W)$, is the result of combining (naturally pressurized) brine and water vapour to extract heat. As the temperature (initially 200 ${ }^{\circ} \mathrm{C}$ ) declines, nanometric amorphous silica precipitates out of the mix, along with sodium and potassium chlorides. This precipitate forms a crust in the pipes that grows at a rate of several centimetres per month and must be periodically removed (3). Part of the brine is reinjected into the subsoil, while the rest is deposited in evaporation lagoons containing thousands of tonnes of this GW, in addition to the crust that accumulates in the pipes. The geothermal plant at Cerro Prieto, Baja California, Mexico, generates approximately 50000 tonnes yearly of this GW, for which no use has yet been found. In light of the foregoing, the present study explored the possibility of using GW as an OPC replacement to provide a solution to this important environmental problem. Such amounts of GW would suffice to enhance 0.5 million tonnes of OPC at a replacement ratio of $10 \%$, which would translate into potential improvement of the quality of around two million cubic metres of concrete. And yet its use in Portland 
alrededor de 2 millones de metros cúbicos de hormigón. Sin embargo, existen pocas referencias en la literatura sobre su uso en hormigones a base de cemento Portland (4).

Considerando lo anterior, se ha encontrado que el reemplazo del CPO por varios materiales ricos en sílice, tales como humo de sílice, ceniza de la cáscara de arroz o sílice amorfa de Hil-Sil, mejoran las propiedades de los morteros y hormigones (5-7). El efecto combinado de microllenado (reduciendo la porosidad) y el comportamiento puzolánico (reacción con el $\mathrm{Ca}(\mathrm{OH})_{2}$ generado por la hidratación del cemento) proporcionan esas ventajas $(8,9)$. Es también conocido que muchos materiales de reemplazo, como los mencionados, aceleran de manera importante la hidratación del cemento $(10,11)$; se ha considerado que las partículas de estos materiales actúan como sitios de nucleación para la precipitación de los productos de hidratación del cemento Portland, tales como el gel $\mathrm{C}-\mathrm{S}-\mathrm{H}$, mejorando las propiedades del cemento.

El empleo de nanosílice (NS) como aditivo del cemento Portland en pastas y morteros ha sido reportado por varios autores. De acuerdo con Gaitero et. al. (12) las partículas de NS modificaron y mejoraron el comportamiento de pastas de cemento Portland hidratadas mediante: la reducción de la porosidad, trasformando la portlandita en $\mathrm{C}-\mathrm{S}-\mathrm{H}$ e incrementando la longitud de las cadenas de silicatos en la estructura interna del C-S-H. También se ha encontrado una microestructura más densa y estable y una mejor unión en los cementos compuestos con adiciones de NS (13), así como una reducción en el $\mathrm{CH}$ en morteros de cemento Portland incorporando NS (14). Qing et. al. (15) realizaron un estudio comparativo del efecto de la adición de NS y humo de sílice en cemento Portland; concluyendo que la NS inducía a un proceso de hidratación más acelerado comparado con el humo de sílice; teniendo como consecuencia el mejoramiento en la resistencia a la compresión, la resistencia de la unión entre el agregado y la pasta y la actividad puzolánica. Li et. al. (16) encontraron también un incremento en la resistencia a la flexión y a la compresión en presencia de nano-partículas $\left(\mathrm{SiO}_{2}\right.$ y $\left.\mathrm{Fe}_{2} \mathrm{O}_{3}\right)$, las cuales, cuando estaban distribuidas uniformemente, actuaban no solamente como micro-rellenadores, de acuerdo con sus observaciones en MEB, sino promoviendo la hidratación y mejorando la microestructura de las pastas de cemento. Los autores sugieren que una gran cantidad de nano-partículas distribuidas en la pasta de cemento pueden unirse fuertemente con los productos de hidratación cerca de la zona de transición, de manera tal que la unión entre las nano-partículas y los productos hidratados inhiben el crecimiento de $\mathrm{CH}$ y AFm previamente formadas; estos cristales finos favorecen la resistencia de la pasta de cemento. cement concrete has received scant attention in the literature (4).

The replacement of OPC with silica-rich materials such as silica fume, rice husk ash and Hi-Sil (a commercial amorphous silica) has been found to improve mortar and concrete properties (5-7) due to the combined effect of particle packing (reduced porosity) and pozzolanicity (reaction with the $\mathrm{Ca}(\mathrm{OH})_{2}$ generated by cement hydration) $(8,9)$. Many of such replacement materials are also widely known to accelerate cement hydration $(10,11)$ through a process in which their particles are thought to act as nucleation sites for the precipitation of Portland cement hydration products such as $\mathrm{C}-\mathrm{S}-\mathrm{H}$. The ultimate outcome is an improvement in cement properties.

A number of authors have reported the use of nanosilica (NS) as an admixture in Portland cement pastes and mortars. Gaitero et al. (12) reported that NS particles modified and improved hydrated Portland cement paste behaviour by reducing porosity, transforming the portlandite into $\mathrm{C}-\mathrm{S}-\mathrm{H}$ and increasing the average chain length in the internal structure of the $\mathrm{C}-\mathrm{S}-\mathrm{H}$. Paste microstructure has also been found to be denser and more stable, and composite cements with NS additions have been observed to form better bonds (13). Moreover, lower $\mathrm{CH}$ concentrations have been detected in NS-containing Portland cement mortars (14). Qing et al (15) described a comparative study on the effect of adding NS and silica fume to Portland cement in which they concluded that NS induced speedier hydration than the fume. This was consistent with improvements in compressive strength, the strength of the aggregate-paste bond and pozzolanic activity. Li et al. (16) also observed bending and compressive strength to rise in the presence of nanoparticles $\left(\mathrm{SiO}_{2}\right.$ and $\left.\mathrm{Fe}_{2} \mathrm{O}_{3}\right)$ which, when evenly distributed, acted not only as particle packers, further to the authors' SEM observations, but also fostered hydration and improved cement paste microstructure. They suggested that large amounts of nanoparticles distributed throughout the cement paste might bond tightly to hydration products near the transition zone. This bond would inhibit the growth of previously formed $\mathrm{CH}$ and AFm, whose fine crystals would enhance cement paste strength. 


\section{PROCEDIMIENTO EXPERIMENTAL}

Debido a que la información sobre el uso de DG como material de reemplazo del CPO es muy limitada, se realizó una investigación extensiva con el propósito de conocer más detalladamente el comportamiento del DG y su efecto en la hidratación del cemento. En este artículo se presentan los resultados de Difracción de Rayos X Cuantitativa (DRXQ), para analizar el efecto de la adición de DG sobre la hidratación de las fases del clínker. También se presentan resultados de microscopía electrónica de barrido (MEB) con imágenes por electrones retrodispersados (IERD) y modo ambiental (ESEM) realizando un análisis de las principales observaciones microestructurales.

Para el desarrollo de este estudio se utilizó un cemento Portland ordinario, con adiciones de calcita en la planta de Cementos Holcim-Apasco (Planta Ramos Arizpe, México). El desecho geotérmico fue proporcionado por la Comisión Federal de Electricidad (Planta Geotérmica de Cerro Prieto, México). La composición química de los materiales, que fue realizada mediante espectrometría de rayos $X$, espectrometría de plasma acoplado inductivamente y vía húmeda, se presenta en la Tabla 1 . El análisis de fases del cemento fue llevado a cabo mediante DRXQ empleando el método desarrollado por Guttridge (17) que se discute más adelante.

El DG requirió un pretratamiento para eliminar los cloruros de sodio y potasio; para esto se lavó 8 veces con agua a $80^{\circ} \mathrm{C}$, posteriormente se realizó un secado a $105^{\circ} \mathrm{C}$ durante 48 horas, los cloruros remanentes en el desecho fueron de un $3 \%$ en peso aproximadamente. El DG es de color blanco, con una densidad de $2,1 \mathrm{~g} / \mathrm{cm}^{3}$, tamaño de partícula de $20-50 \mathrm{~nm}$ y pérdida de peso por ignición de alrededor de $5 \%$, sus características puzolánicas han sido publicadas con anterioridad (18-20).

Se prepararon pastas cementosas usando agua destilada en una relación agua/sólidos de 0,50 y empleando niveles de reemplazo de 0, 10 y $20 \%$ DG. Debido al tamaño de partícula nanométrico del DG, se utilizó superplastificante en 1 y $1,5 \%$ en peso para las pastas con $10 \%$ y $20 \%$ DG, respectivamente. Se fabricaron probetas cúbicas de $5 \mathrm{~cm}$, que se curaron isotérmicamente a 20 y $60^{\circ} \mathrm{C}$, por períodos

\section{EXPERIMENTAL}

In light of the scant information available on the use of GW as an OPC replacement, extensive research was conducted to obtain a more detailed understanding of the behaviour of this waste and its effect on cement hydration. This study used quantitative $X$-ray diffraction (QXRD) techniques to analyze the effect of GW on clinker phase hydration. Paste microstructure was characterized with scanning electron microscope (SEM) analysis using backscattered electron and environmental SEM imaging.

The calcite-additioned Portland cement used was supplied by Cementos Holcim-Apasco (Planta Ramos Arizpe, Mexico). The geothermal waste was furnished by Mexico's Federal Electricity Commission (Cerro Prieto Geothermal Plant, Mexico). The chemical composition of the materials, determined with $X$-ray spectrometry, inductively coupled plasma spectrometry and wet chemistry techniques, is given in Table 1. Cement phases were analyzed with QXRD using the method developed by Guttridge (17) discussed below.

The GW was rinsed eight times with water at $80^{\circ} \mathrm{C}$ to remove the sodium and potassium chlorides, after which the samples were dried at $105{ }^{\circ} \mathrm{C}$ for 48 hours. The chlorides remaining in the waste accounted for approximately $3 \%$ of the total weight. GW is white, has a density of $2.1 \mathrm{~g} / \mathrm{cm}^{3}$, a particle size of $20-50 \mathrm{~nm}$ and a $5 \%$ (wt) loss on ignition. Its pozzolanic properties have been published elsewhere (18-20).

Cement pastes were prepared with a distilled water/solid ratio of 0.50 and replacement ratios of 0,10 and $20 \%$ GW. Due to the nanometric scale of the GW particles, 1 and $1.5 \%$ superplasticizer was added to the pastes containing 10 and 20\% waste, respectively. Five-cm cubic specimens were prepared and cured isothermally at 20 and $60^{\circ} \mathrm{C}$ for 3, 7, 14, 28, 90 and 360 days. After

Tabla 1 / Table 1

Composición química y de fases del desecho geotérmico y del cemento Portland.

Chemical and phase composition of the geothermal waste and Portland cement.

\begin{tabular}{|c|c|c|c|c|c|c|c|c|c|c|c|}
\hline & $\mathbf{S i O}_{\mathbf{2}}$ & $\mathbf{C a O}$ & $\mathbf{A l}_{2} \mathbf{O}_{\mathbf{3}}$ & $\mathbf{F e}_{\mathbf{2}} \mathbf{O}_{\mathbf{3}}$ & $\mathbf{M g O}$ & $\mathbf{N a}_{\mathbf{2}} \mathbf{O}$ & $\mathbf{K}_{\mathbf{2}} \mathbf{O}$ & $\mathbf{T i O}_{\mathbf{2}}$ & $\mathbf{M n O}$ & $\mathbf{S O}_{\mathbf{3}}$ & $\mathbf{T o t a l}$ \\
\hline $\mathrm{DG} / \mathrm{GW}$ & 94.67 & 1.72 & 1.04 & - & 0.53 & 0.66 & 0.53 & 0.84 & - & - & 99.99 \\
\hline $\mathrm{CPO} / \mathrm{OPC}$ & 18.16 & 67.53 & 3.50 & 2.52 & 1.89 & 1.89 & 0.57 & - & 0.14 & 4.05 & 99.23 \\
\hline
\end{tabular}

\begin{tabular}{|c|c|c|c|c|c|c|c|c|}
\hline Fase / Phase & $\mathbf{C}_{\mathbf{3}} \mathbf{S}$ & $\mathbf{C}_{\mathbf{2}} \mathbf{S}$ & $\mathbf{C}_{\mathbf{3}} \mathbf{A}$ & $\mathbf{C}_{\mathbf{4}} \mathbf{A F}$ & Calcita / Calcite & Yeso / Gypsum & Cuarzo / Quartz & Total \\
\hline$\%$ & 66.9 & 7.3 & 2.4 & 7.2 & 8.2 & 2.7 & 4.8 & 99.5 \\
\hline
\end{tabular}


de $3,7,14,28,90$ y 360 días. Después de estos períodos de curado, las muestras fueron secadas en vacío a $105^{\circ} \mathrm{C}$ durante 24 horas.

Debido a que los productos de hidratación son por lo general pobremente cristalinos, para poder estimar el grado de hidratación de los cementos sustituidos se dio seguimiento a la desaparición de las fases cristalinas del clínker (alita, belita, aluminato y ferrita) mediante DRX. Fue llevado a cabo mediante una técnica cuantitativa basada en un estándar interno $\left(\mathrm{TiO}_{2}\right)$ y fue desarrollada por Guttridge en la British Cement Association (17). Para el análisis por DRXQ las muestras se molieron en un molino de bolas con contenedores de ágata hasta pasar por una malla de 106 $\mu \mathrm{m}$; posteriormente se mezclaron con rutilo (usado como estándar interno), en relación 5:1 cemento:rutilo, y se trataron nuevamente en el molino planetario usando ciclohexano, como ayuda de molienda, durante 20 minutos. Las condiciones utilizadas para el análisis por DRXQ fueron las señaladas por Gutteridge, con un rango de 24 a $39^{\circ} 2 \theta$, tamaño de paso de 0,05 y tiempo de incidencia de 20 segundos. El análisis está basado en un programa que emplea el método de mínimos cuadrados para ajustar dos patrones de DRX de la siguiente manera:

(1) Un patrón de DRX de la muestra problema con el estándar interno.

(2) Un patrón simulado que incluye los patrones de DRX de un grupo de estándares.

Los estándares empleados en el punto (2) fueron obtenidos de compuestos que pueden existir en el cemento Portland y fueron desarrollados en el laboratorio por Guttridge. A partir del ajuste de las curvas 1 y 2 previamente mencionadas se calcula la fracción en peso de las fases remanentes y de esta manera se estima el grado de hidratación de cada una de ellas y el grado de hidratación total. El empleo de esta técnica ha sido reportado en la literatura por otros autores $(21,22)$.

Las muestras para análisis por MEB-IERD se tomaron de fragmentos de pastas curadas por 360 días, éstas se montaron en frío en resina; se desbastaron con lijas de $\mathrm{SiC}$ y se pulieron con pasta de diamante hasta $1 / 4 \mu \mathrm{m}$. Se observaron también muestras en MEB-ESEM con la finalidad de impedir que el secado de la muestra afectara la morfología de las fases durante el análisis.

\section{RESULTADOS Y DISCUSIÓN}

\subsection{Resultados de Difracción de Rayos X}

Los resultados de DRXQ del grado de hidratación total (GHT), en función del nivel de reemplazo de cemento, se presentan en la Figura 1. En general, se observó que curing, the samples were vacuum dried at $105^{\circ} \mathrm{C}$ for 24 hours.

Since hydration products are usually poorly crystalline, the degree of hydration of the neat and blended cements was estimated by XRD following the disappearance of the clinker crystalline phases (alite, belite, aluminate and ferrite). This involved quantitative analysis based on a technique involving an internal standard $\left(\mathrm{TiO}_{2}\right)$ developed by Guttridge in the British Cement Association (17). The samples were ground in a ball grinder with agate cups to a size that passed a $106 \mu \mathrm{m}$ sieve. They were subsequently mixed with rutile (used as an internal standard) at a cement:rutile ratio of 5:1 and then ground in a planetary grinder for 20 minutes, using cyclohexane as a grinding aid. The QXRD conditions used for the analysis were as specified by Gutteridge: $2 \theta$ diffraction angle range, 240 to 390; step size, 0.05 and 20 seconds per step. The analysis was based on software in which the minimum squares method was used to fit two XRD traces as follows:

(1) A diffractogram for a problem sample containing the internal standard.

(2) A simulated diffractogram containing the XRD patterns for a series of standards.

The standards used in point (2) were developed by Guttridge in the laboratory from the compounds that may be found in Portland cement. Fitted curves 1 and 2 were then used to calculate the fraction by weight of the clinker phases and estimate the degree of hydration of each as well as the overall degree of hydration. This technique has also been used by other authors $(21,22)$.

The SEM-BEI samples were prepared with 360-day paste fragments mounted in resin, ground with SiC sandpaper and polished down with diamond paste to $1 / 4 \mu \mathrm{m}$. The samples were also observed under ESEM to prevent sample drying from affecting phase morphology during the analysis.

\section{RESULTS AND DISCUSSION}

\subsection{X-Ray Diffraction}

The QXRD findings on the overall degree of hydration $(O D H)$ in the cement pastes studied are shown in Figure 1. Generally speaking, in all the cement blends (0, 10 and 
para todas las mezclas de cemento $(0,10$ y $20 \%$ de DG), los mayores valores de hidratación en etapas tempranas fueron para las pastas curadas a $60^{\circ} \mathrm{C}$, por otro lado, los máximos valores de GHT en el largo plazo fueron alcanzados por las pastas curadas a $20^{\circ} \mathrm{C}$. Este comportamiento de altos GHT a alta temperatura en etapas tempranas e, inversamente, a largo plazo respecto a bajas temperaturas ha sido estudiado y discutido para otros cementos puros y sustituidos (11). La mezcla que obtuvo el máximo GHT fue la de $10 \%$ DG, seguida por las pastas con 20 y $0 \%$ DG.

Para cada temperatura, el GHT de ambos cementos sustituidos fue mayor comparado con el del CPO puro. El incremento en el GHT para los cementos sustituidos puede ser debido a dos factores muy importantes: (a) Las partículas de DG sirvieron como sitios de nucleación, acelerando las reacciones de hidratación del cemento y (b) el DG consumió el hidróxido de calcio, ya que su reducción desplaza el equilibrio de la reacción de la alita y belita y tiende a incrementar la formación de más silicato de calcio hidratado.
$20 \% \mathrm{GW})$, the highest early age hydration values were observed for the pastes cured at $60^{\circ} \mathrm{C}$, whereas the highest long-term $\mathrm{ODH}$ values were reached by the pastes cured at $20^{\circ} \mathrm{C}$. Similar findings, i.e., high early age $\mathrm{ODH}$ values at high curing temperatures and high long-term values at low temperatures, have been reported and discussed for other neat and blended cements (11). The blend containing 10\% GW exhibited the highest $O D H$, followed by the pastes with 20 and $0 \% \mathrm{GW}$.

The $\mathrm{ODH}$ for the cements containing the replacement was higher at each temperature than for the neat OPC. The increase in $\mathrm{ODH}$ in the former may be due to two very important factors: (a) the GW particles acted as nucleation sites, accelerating cement hydration reactions and (b) the GW consumed calcium hydroxide, whose reduction shifts the alite - belite reaction equilibrium, thereby inducing the formation of more hydrated calcium silicate.

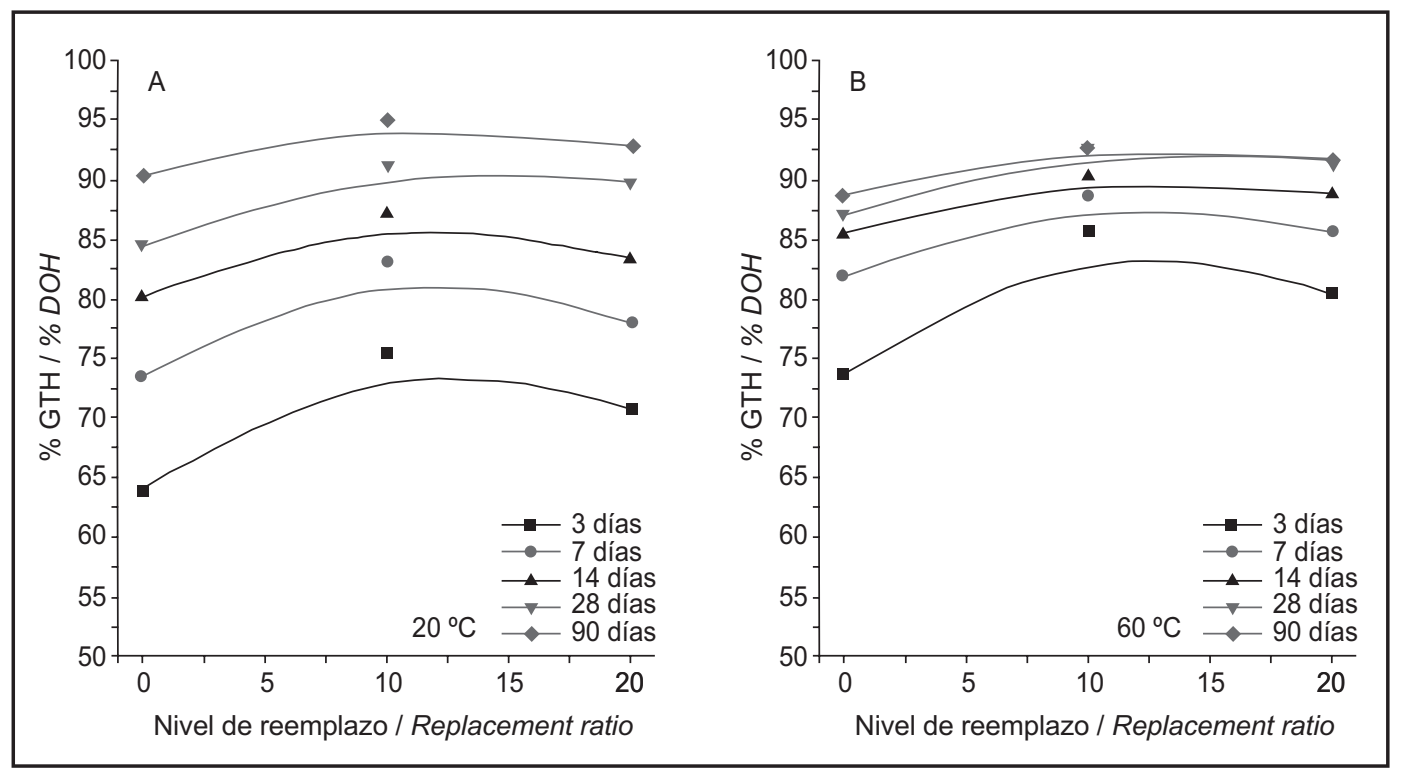

Figura 1. Grado de hidratación total vs. Nivel de reemplazo, para (A) pastas curadas a $20^{\circ} \mathrm{C}$ y (B) pastas curadas a $60^{\circ} \mathrm{C}$. Figure 1. Overall degree of hydration vs. replacement ratio for $(A)$ pastes cured at $20^{\circ} \mathrm{C}$ and $(B)$ pastes cured at $60^{\circ} \mathrm{C}$.

\subsection{Resultados de microscopía electrónica de barrido: evaluación de microestructura y porosidad}

La Figura 2 presenta los resultados de caracterización microestructural por MEB-IERD de pastas de cementos con 0,10 y $20 \%$ de DG, curadas a $20^{\circ} \mathrm{C}$. Adicionalmente se estimó la porosidad mediante análisis de imágenes para cada una de las pastas, para esto se usó el programa

\subsection{Scanning electron microscopy: microstructure and porosity}

Figure 2 shows the SEM-BEI microstructural findings for cement pastes with 0, 10 and $20 \% \mathrm{GW}$, cured at $20^{\circ} \mathrm{C}$. Porosity was estimated by analyzing the images for each paste with The Gimp (GNU-GPL) (23), Linux open-source software. The results are also shown in Figure 2. The 
The Gimp (GNU-GPL) (23) en la plataforma Linux; los resultados se muestran también en la Figura 2 . El análisis de las imágenes se basó en la metodología propuesta por Scrivener (24), procesando 10 imágenes por muestra y manteniendo las condiciones de operación del MEB constantes (brillo, contraste, tiempo de exposición de la fotografía, diámetro del haz y aumentos). images were analyzed using methodology proposed by Scrivener (24) in which 10 images per sample were processed under constant SEM operating conditions (brightness, contrast, photograph exposure time, spot size and magnification).

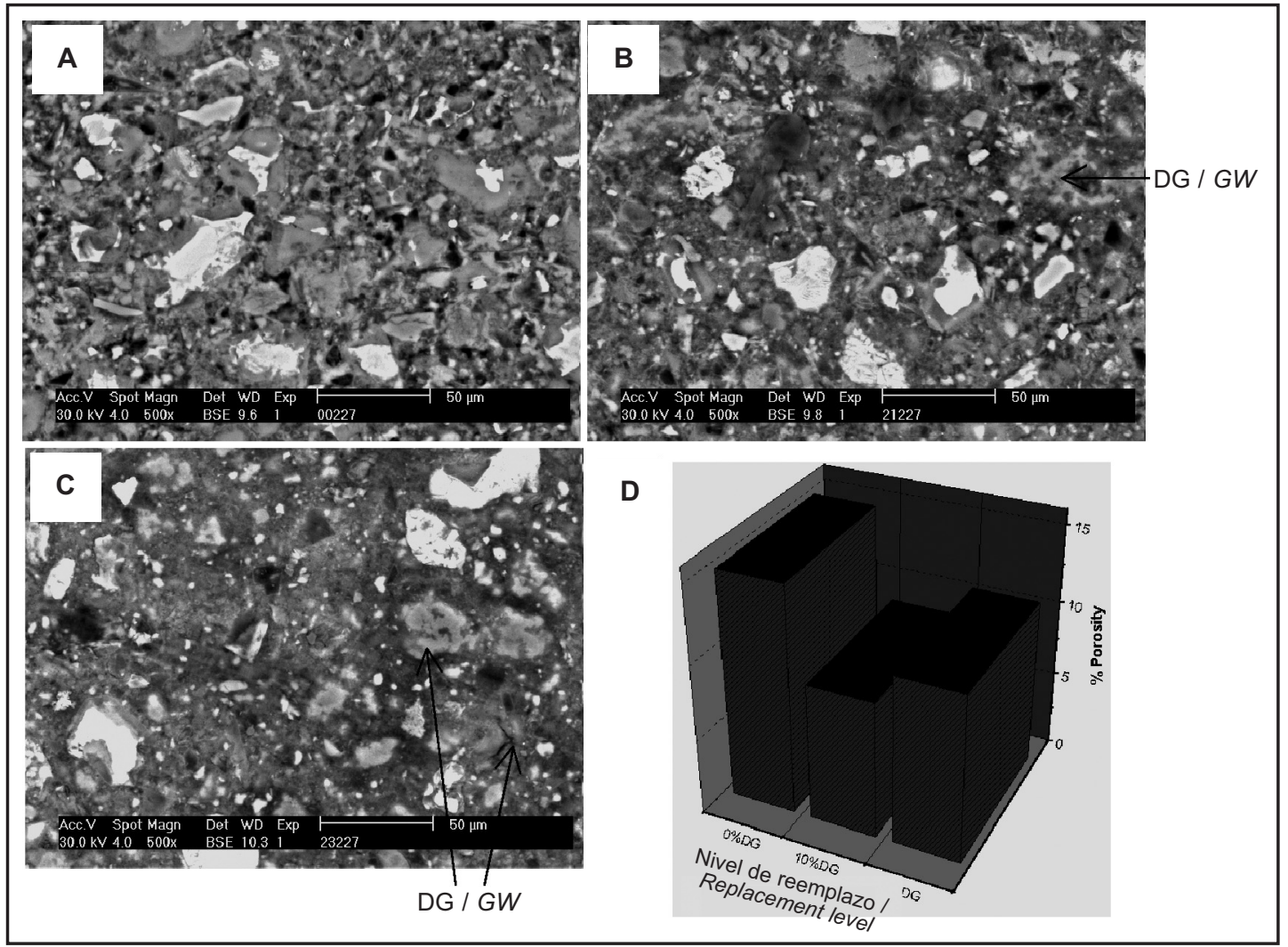

Figura 2. Microestructuras por MEB-IERD de pastas de cemento curadas a $20^{\circ} \mathrm{C}$, con (A) $0 \%$ DG, (B) $10 \%$ DG y (C) $20 \%$ DG. (D) Gráfico del porcentaje de porosidad para las microestructuras $A, B$ y $C$.

Figure 2. SEM-BEI microstructures of cement pastes cured at $20{ }^{\circ} \mathrm{C}$ with A) $0 \% \mathrm{GW}$, (B) $10 \% \mathrm{GW}$ and (C) $20 \% \mathrm{GW}$. (D) Graph of the porosity percentage for the microstructures $A, B$ and $C$.

Las características principales encontradas para el CPO puro (Figura $2 \mathrm{~A}$ ) fueron las comúnmente reportadas para pastas de cemento con relación agua/sólidos de 0,50; con una fracción de cemento sin reaccionar, con cristales de $\mathrm{CH}$ y porosidad dispersa en la matriz. En comparación con la microestructura del CPO puro, en los cementos compósitos (Figura 2B y C) se observó una reducción en la porosidad (Figura $2 \mathrm{D}$ ) y en el contenido de $\mathrm{CH}$. Es muy importante notar que las microestructuras de los cementos compuestos mostraron una matriz más compacta, lo que resalta el efecto de microllenado del DG.

Las partículas de DG (identificadas en las figuras) mostraron aglomeración con morfología irregular. Además, la tonalidad de gris de estos aglomerados
The main characteristics observed for neat OPC (Figure $2 A)$ fell within the main features reported for cement pastes with a water/cement ratio of 0.50 , including a fraction of unreacted cement, $\mathrm{CH}$ crystals and a matrix with scattered pores. By comparison, the composite cements (Figure $2 B$ and $C$ ) were observed to be less porous (Figure 2D) and have a smaller $\mathrm{CH}$ content. One relevant finding was the more compact matrix in the blended cements as a result of GW particle packing.

The GW particles (identified in the figures) clustered and exhibited irregular morphology. The shade of grey of these clusters changed with the reaction stage: the outer 
cambió dependiendo del estado de la reacción, mostrando anillos externos de un gris más claro que fueron identificados como productos de reacción.

Cuando se compararon las microestructuras de los cementos con 10 y $20 \%$ DG, en las últimas se encontraron más aglomerados y de mayor tamaño, alcanzando hasta 100 $\mu \mathrm{m}$, que, a su vez, mostraron grados de reacción menores. Este fenómeno es muy importante, ya que puede estar asociado con el fenómeno de la formación de gel de reacción álcali sílice observado en algunos de los cementos compuestos hidratados bajo ciertas condiciones de curado, como se describe posteriormente; se observó también que en ausencia de estos aglomerados en las pastas de cemento, dicha reacción nociva no ocurrió.

\subsection{Evaluación de la presencia de gel de reacción álcali sílice, ettringita y sal de Friedel}

Aun cuando los resultados anteriores muestran las propiedades puzolánicas (disminución del $\mathrm{CH}$ de acuerdo con las microestructuras), la aceleración de la hidratación de las fases del cemento (por DRXQ) y de rellenador de huecos (matrices más compactas) del DG; durante la hidratación de los cementos compuestos, se encontró un problema de agrietamiento extensivo en las pastas con altos contenidos de DG (20\%). Este fenómeno se inició a partir de los 14 días, con daños severos a los 90 días para pastas curadas a $60^{\circ} \mathrm{C}$ y, para las pastas curadas a $20^{\circ} \mathrm{C}$, se observó hasta los 360 días.

En un amplio estudio realizado en MEB (ESEM e IERD) se encontró la presencia de gel de reacción álcali sílice (RAS), ettringita y sal de Friedel en pastas con 20\% DG. La Figura 3 muestra zonas de fractura obtenidas por ESEM, donde se encontró abundante gel RAS y ettringita, esto para muestras curadas durante 360 días a 20 y $60{ }^{\circ} \mathrm{C}$. La Figura 4 muestra microestructuras obtenidas por IERD para muestras curadas a $20^{\circ} \mathrm{C}$ por 360 días, donde se detectó también una formación importante de gel RAS como formador de grietas y sal de Friedel. Esta última fase no se encontró en etapas tardías en las pastas curadas a $60{ }^{\circ} \mathrm{C}$, ya que generalmente se lixivia y dicha disolución se acelera con la temperatura. Sin embargo, dicha sal se encontró únicamente a 1, 3 y 7 días de hidratación a $60{ }^{\circ} \mathrm{C}$ y, en fechas posteriores, se observó el gel de RAS.

De acuerdo con lo anterior, existe la posibilidad de que los cloruros remanentes en el DG promovieran la liberación de iones hidroxilo y la formación de la sal de Friedel de acuerdo a la siguiente reacción [1]: rings, lighter in colour, were identified as reaction products.

A comparison of the microstructures in the 10 and $20 \%$ blends showed that the latter had more and larger clusters, up to $100 \mu \mathrm{m}$ across, but with lower degrees of reaction. This is an important observation and may be associated with the formation of the alkali silica reaction gel found in some of the composite cements studied, as described below. No such detrimental reaction was observed in the absence of these clusters.

\subsection{Presence of alkali silica reaction gel, ettringite and Friedel's salt}

The aforementioned findings showed that GW has pozzolanic properties ( $\mathrm{CH}$ consumption detected in the microstructural analysis), accelerates cement phase hydration (QXRD analysis) and fills pores (more compact matrices). Nonetheless, the blended cements containing a high (20\%) GW ratio were observed to crack extensively during hydration. Cracks were visible after 14 days, with severe damage observed in 90-days pastes cured at $60^{\circ} \mathrm{C}$ and 360 -day specimens cured at $20^{\circ} \mathrm{C}$.

A SEM (ESEM and BEI) study revealed the presence of alkali silica reaction (ASR) gel, ettringite and Friedel's salt in the pastes containing $20 \%$ GW. Figure 3 shows the fracture areas obtained with ESEM, where substantial ASR and ettringite were observed in 360-day samples cured at 20 and $60^{\circ} \mathrm{C}$. The microstructure found with $B E I$ for the 360-day samples cured at $20^{\circ} \mathrm{C}$ are shown in Figure 4, where large amounts of both ASR gel, the crack inducer, and Friedel's salt were observed. Since the salt tends to leach and this process is expedited at higher temperatures, it was not detected in the later age pastes cured at $60^{\circ} \mathrm{C}$. Rather, the salt was detected at 1, 3 and 7 days, and only ASR was identified afterwards.

Further to the foregoing, the chlorides remaining in the GW may have induced the release of hydroxyl ions and the formation of Friedel's salt in accordance with the following reaction [1]:

$$
\mathrm{C}_{3} \mathrm{~A}+2 \mathrm{NaCl}+\mathrm{Ca}(\mathrm{OH})_{2}+10 \mathrm{H}_{2} \mathrm{O} \rightarrow \mathrm{C}_{3} \mathrm{~A} \cdot \mathrm{CaCl}_{2} \cdot 10 \mathrm{H}_{2} \mathrm{O}+2 \mathrm{Na}^{+}+2(\mathrm{OH})^{-}
$$




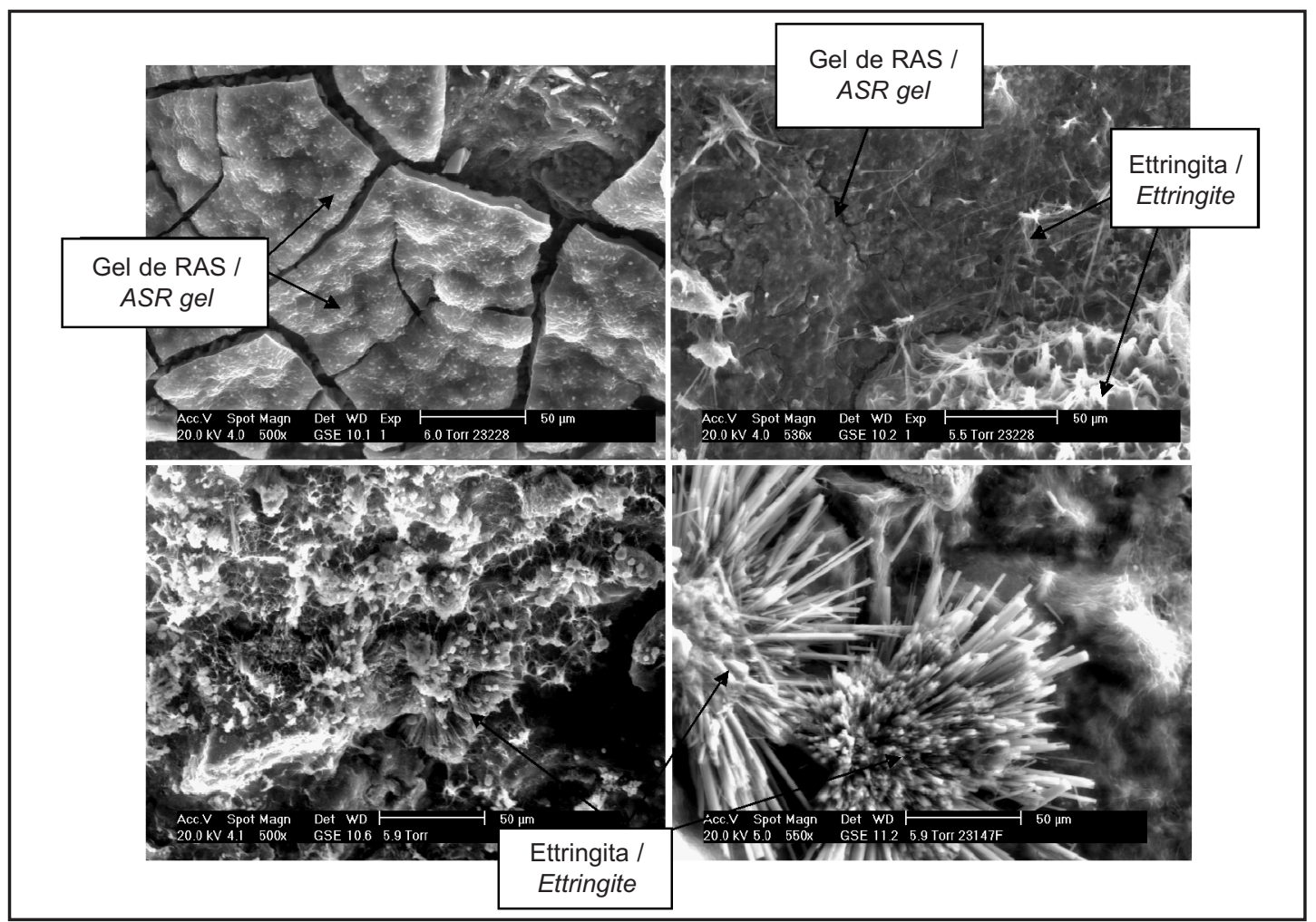

Figura 3. Análisis de zonas de fractura por MEB modo ambiental de pastas curadas a (A) y (B) $20^{\circ} \mathrm{C}$, (C) y (D) $60^{\circ} \mathrm{C}$, durante 360 días.

Figure 3. Analysis of fracture zones by ESEM of pastes cured at $(A)$ and $(B) 20^{\circ} \mathrm{C},(C)$ and $(D) 60^{\circ} \mathrm{C}$, during 360 days.

A su vez, esto pudo haber promovido la formación de gel de RAS (debido a la liberación de los iones Na y K) y ettringita [2] [3]:
This in turn may have induced the ASR gel (due to the release of $\mathrm{Na}$ and $\mathrm{K}$ ions) and ettringite formation [2] [3]:

$$
\begin{gathered}
2 \mathrm{Na}+2 \mathrm{OH}^{-}+\mathrm{CaSO}_{4} \cdot 2 \mathrm{H}_{2} \mathrm{O} \rightarrow \mathrm{Ca}(\mathrm{OH})_{2}+2 \mathrm{Na}^{+}+\mathrm{SO}_{4}^{-2} \\
3 \mathrm{CaO} \cdot \mathrm{Al}_{2} \mathrm{O}_{3}+3\left(\mathrm{CaSO}_{4} \cdot 2 \mathrm{H}_{2} \mathrm{O}\right)+26 \mathrm{H}_{2} \mathrm{O} \rightarrow 3 \mathrm{CaO} \cdot \mathrm{Al}_{2} \mathrm{O}_{3} \cdot 3 \mathrm{CaSO}_{4} \cdot 32 \mathrm{H}_{2} \mathrm{O}
\end{gathered}
$$

La formación inicial de la sal de Friedel inhibe la generación del monosulfato y promueve la formación de ettringita tardía, este fenómeno ha sido confirmado por otros autores (25). Como se mencionó antes, con el incremento en la cantidad de DG el tamaño de los aglomerados del mismo aumentó, lo que puede ser muy dañino en cementos con niveles moderados de álcalis. Se relaciona con el hecho conocido de que el humo de sílice densificado (que puede contener algunos aglomerados en forma de esferas y con tamaño de partícula efectivo en el rango de multi-micras), puede no solamente reaccionar para producir gel de RAS $(26,27)$, sino que este gel puede ser extremadamente perjudicial, especialmente después de un tratamiento térmico.

De las observaciones realizadas en MEB-IERD se encontró que el $\mathrm{DG}$ consumió gran parte del $\mathrm{CH}$, mostrando un comportamiento puzolánico, a pesar de la formación de gel de RAS. Una reacción puzolánica es la que se produce
The early age formation of Friedel's salt inhibited the generation of monosulfate and induced later ettringite formation. This observation concurred with the reported by other authors (25). As noted earlier, the size of the GW clusters grew with increasing amounts of waste. This process, which may be very detrimental in cements with a moderate alkali content, is related to the known fact that dense silica fume (which may contain spherical clusters and effective particle sizes in the multi-micron range) may react to yield ASR gel $(26,27)$. The presence of this gel may be extremely damaging after thermal treatment.

SEM-BEI observations showed that despite the formation of ASR gel, the GW exhibited pozzolanic behaviour, consuming substantial amounts of $\mathrm{CH}$. Pozzolanic reactions take place between the silica and cement in the 
entre la sílice y el cemento en la solución de los poros, en donde las concentraciones de álcalis son bajas. Si las concentraciones de hidróxidos de álcalis son altas (como lo describen las reacciones presentadas), y las partículas de sílice tienen un tamaño significativo (como los aglomerados de GW relativamente grandes), es probable que los cementos sustituidos experimenten formación de gel de RAS. Por otro lado, si la sílice es extremadamente fina, ésta se combina rápidamente con el calcio disponible para formar $\mathrm{C}-\mathrm{S}-\mathrm{H}$, sin efectos negativos. También se ha encontrado que la concurrencia de ettringita y gel de reacción álcali sílice es extremadamente común y se observa en muchos casos de campo de formación de etringita tardía (28). pore solution where alkali concentrations are low. If alkali hydroxide concentrations are high (as described in the reactions presented above) and the silica particles are of a significant size (such as relatively large GW clusters), ASR gel will in all likelihood form in cements containing replacements. If silica particles are extremely fine, however, they combine quickly with the available calcium to form $\mathrm{C}-\mathrm{S}-\mathrm{H}$, with no adverse effects. The concurrence of ettringite and alkali silica reaction gel has also been found to be extremely common in field observations of delayed ettringite formation (28).

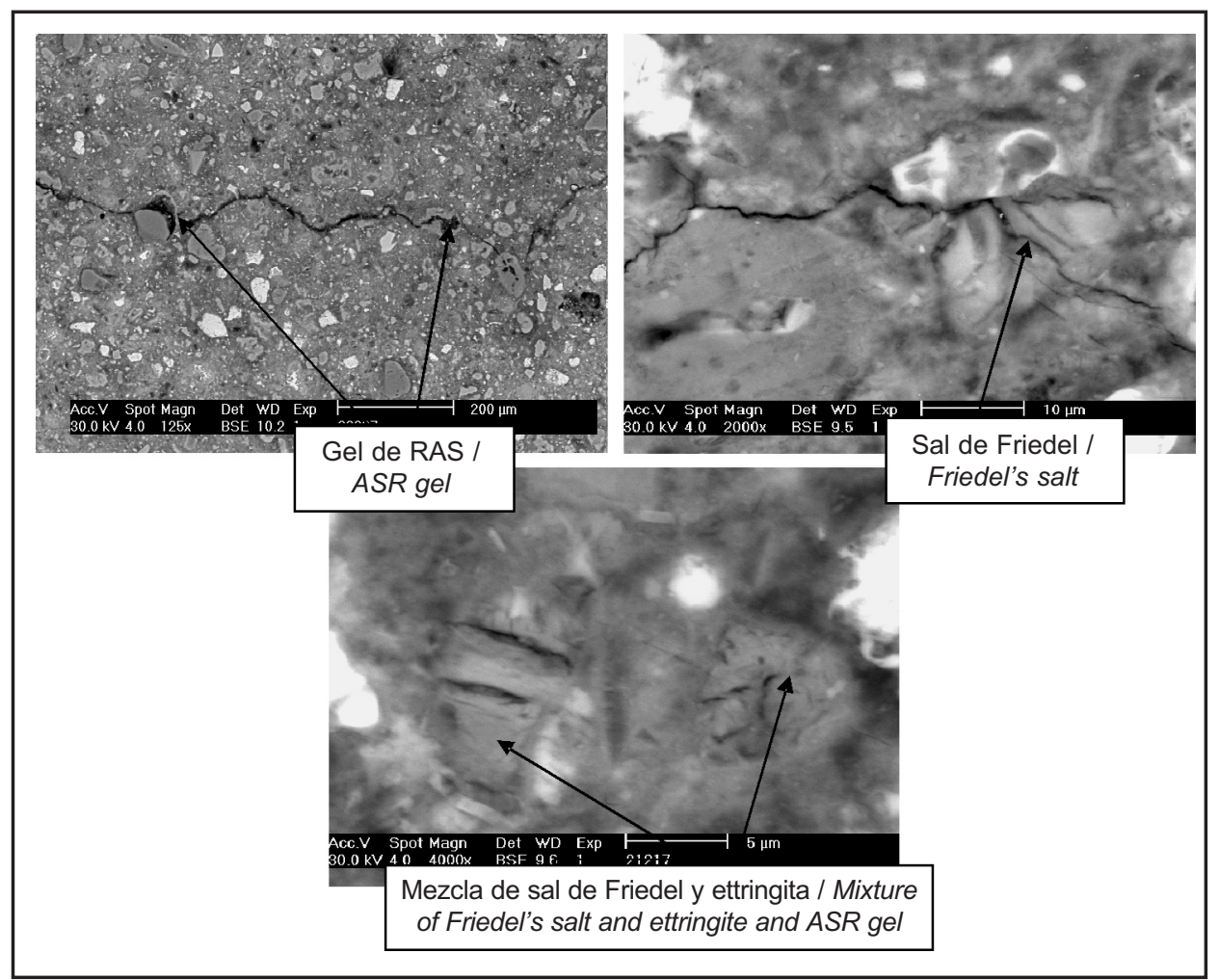

Figura 4. Microestructuras con imágenes por electrones retrodispersados de cementos compuestos con 20\% DG curados a $20^{\circ} \mathrm{C}$ durante 360 días.

Figure 4. Microstructures obtained by backscattered electron images of composite cements with $20 \%$ GW cured at $20^{\circ} \mathrm{C}$ during 360 days.

\section{CONCLUSIONES}

- La hidratación del cemento se aceleró en presencia del desecho geotérmico, de acuerdo con los resultados de difracción de rayos $\mathrm{X}$ cuantitativa.

- La presencia del desecho geotérmico tuvo como resultado una reducción en la porosidad, obteniendo matrices más compactas; adicionalmente el hidróxido de calcio se consumió en la reacción puzolánica, formando más productos de hidratación.

\section{CONCLUSIONS}

- Further to the quantitative $X$-ray diffraction findings, cement hydration was accelerated in the presence of geothermal waste.

- The presence of geothermal waste led to lower porosity and more compact matrices, while calcium hydroxide was consumed in the pozzolanic reaction, forming more hydration product. 
- Las pastas con 20\% DG presentaron agrietamiento extensivo, que fue atribuido a la formación inicial de sal de Friedel, lo que ocasionó la creación de gel de reacción álcali sílice y de formación tardía de ettringita.

- En general puede decirse que la presencia del desecho influyó significativamente en la hidratación y la microestructura del cemento Portland
- Pastes containing $20 \%$ GW exhibited extensive cracking, attributed to the early formation of Friedel's salt that induced the generation of alkali silica reaction gel and later age ettringite formation.

- Overall, the presence of the waste had a significant impact on Portland cement hydration and microstructure.

\section{BIBLIOGRAFÍA / BIBLIOGRAPHY}

(1) Taylor, H. F. W.: Cement Chemistry, segunda edición, Telford Publishing, 1997. doi:10.1680/cc.25929

(2) Patente: "Process for using sludge from geothermal brine to make concrete and concrete composition". Número de patente: 4900360. Inventores: Olin D. Whitescarver, Indian Wells; Jonathan T. Kwan (1990), E. U.

(3) Díaz, C.; Rincón, J. M.: "Tratamiento químico de la escoria de sílice de una planta geotérmica para su aplicación en cerámica y vidrio", Boletín de la Sociedad Española de Cerámica y Vidrio, vol. 29 (1990), pp. 181-184.

(4) Gómez-Zamorano, L. Y.: Tesis doctoral: "Geothermal waste as a replacement material of Portland cement pastes", Cinvestav - Unidad Saltillo, México (2004).

(5) Toutanji, H. A.; El-Korchi, T.: "The influence of silica fume on the compressive strength on cement paste and mortar", Cem. Concr. Res., vol. 25 (1995), pp. 1591-1602. doi:10.1016/0008-8846(95)00152-3

(6) Nehdi, M.; Duquette, J.; El Damaty, A.: "Performance of rice husk ash produced using a new technology as a mineral admixture in concrete", Cem. Concr. Res., vol. 33 (2003), pp. 1203-1210. doi:10.1016/S0008-8846(03)00038-3

(7) Anderson, D.; Roy, A.; Seals, R. K.; Cartledge, F. K.; Akhter, H.; Jones, S. C.: "A preliminary assessment of the use of an amorphous silica residual as a supplementary cementing material", Cem. Concr. Res., vol. 30 (2000), pp. 437-445. doi:10.1016/S0008-8846(99)00269-0

(8) Cheng-Yi, H.; Feldman, R. F.: "Hydration Reactions in Portland Cement - Silica Fume Blends", Cem. Concr. Res., vol. 15 (1985), pp. $582-592$.

(9) Yogendran, V.; Langan, B. W.; Ward, M. A.: "Hydration of cement and silica fume paste", Cement and Concrete Research, vol. 21 (1991), pp. 691-708. doi:10.1016/0008-8846(91)90164-D

(10) Gutteridge, W. A.; Dalziel, J. A.: "The effect of a secondary component on the hydration of Portland cement, Part I, Fine hydraulic binders", Cem. Concr. Res., vol. 20 (1990), pp. 853-861. doi:10.1016/0008-8846(90)90046-Z

(11) Escalante-García, J. I.; Sharp, J. H.: "Effect of temperature on the hydration of the main clinker phases in Portland cements: Part II, blended cements", Cem. Concr. Res., vol. 28 (1998), pp. 1259. doi:10.1016/S0008-8846(98)00107-0

(12) Gaitero, J. J.; Campillo, I.; Guerrero, A.: "Reduction of the calcium leaching rate of cement paste by addition of silica nanoparticles", Cem. Concr. Res. (2008). doi:10.1016/j.cemconres.2008.03.021

(13) Shih, J. Y.; Chang, T. P.; Hsiao, T. C.: "Effect of nanosilica on characterization of Portland cement composite", Materials Science and Engineering A, vol. 424 (2006), pp. 266-274. doi:10.1016/j.msea.2006.03.010

(14) Jo B. W.; Kim C. H.; Tae, G.; Park, J. B.: "Characteristics of cement mortar with nano-SiO 2 particles", Construction and Building Materials, vol. 21 (2007), pp. 1351-1355. doi:10.1016/j.conbuildmat.2005.12.020

(15) Qing, Y.; Zenan, Z.; Deyu, K.; Rongshen, C.: "Influence of nano- $\mathrm{SiO}_{2}$ addition on properties of hardened cement paste as compared with silica fume", Construction and Building Materials, vol. 21 (2007), pp. 539-545. doi:10.1016/j.conbuildmat.2005.09.001

(16) Li, H.; Xiao, H. G.; Yuan, J.; Ou J.: "Microstructure of cement mortar with nano-particles", Composites: Part B 35 (2004), pp. 185-189. doi:10.1016/S1359-8368(03)00052-0

(17) Gutteridge, W. A.: "Quantitative X-Ray Powder Diffraction In The Study Of Some Cementive Materials", British Ceramics Proceedings, no 35, The Chemistry and Chemical Related Properties of Cement (1984), pp. 11-23.

(18) Gómez-Zamorano, L. Y.; Escalante-García, J. I.; Mendoza-Suárez, G.: "Geothermal waste: An alternative replacement material of Portland cement", Journal of Materials Science, 39 (2004), pp. 4021- 4025. doi:10.1023/B:JMSC.0000031486.70227.dc

(19) Escalante-García, J. I.; Mendoza, G.; Mancha, H.; López, J.; Vargas, G.: "Pozzolanic properties of a geothermal silica waste material", Cem. Concr. Res., vol. 29 (1999), pp. 623-625. doi:10.1016/S0008-8846(98)00238-5

(20) Gómez-Zamorano, L. Y., Escalante-García, J. I.: "Effect of the curing temperature on the non evaporable water in Portland cement blended with geothermal waste", Cement and Concrete Composites, en revisión.

(21) Yang, R.; Sharp, J. H.: "Hydration characteristics of Portland cements after heat curing: I, Degree of hydration of the anhydrous cement phases", Journal of American Ceramic Society, vol. 84 (2001), pp. 608-614. doi:10.1111/j.1151-2916.2001.tb00707.x

(22) Escalante-García, J. I.; Sharp, J. H.: "Effect of temperature on the hydration of the main clinker phases in Portland cements: Part I, neat cements", Cem. Concr. Res., vol. 28 (1998), pp. 1245-1257. doi:10.1016/S0008-8846(98)00115-X

(23) http://www.gimp.org/

(24) Scrivener, K. L.: "Backscattered electron imaging of cementitious microstructures: understanding and quantification", Cement and Concrete Composites, vol. 26 (2004), pp. 935-945. doi:10.1016/j.cemconcomp.2004.02.029 
(25) Rémond, S.; Bentz, D. P.; Pimienta, P.: "Effects of the incorporation of Municipal Solid Waste Incineration fly ash in cement pastes and mortars, II: Modeling", Cem. Concr. Res., vol. 32 (2002), pp. 565-576. doi:10.1016/S0008-8846(01)00722-0

(26) Bonen, D.; Diamond, S.: "Occurrence of large silica fume derive particles in hydrated cement paste", Cem. Concr. Res., vol. 22 (1992), pp. 1059-1066. doi:10.1016/0008-8846(92)90036-U

(27) Maas, A. J.; Ideker, J. H.; Juenger, M. C. G.: "Alkali silica reactivity of agglomerated silica fume", Cement and Concrete Research, vol. 37 (2007), pp. 166-174. doi:10.1016/j.cemconres.2006.10.011

(28) Diamond, S.: personal communication. 